\title{
Black Diaphragm Intraocular Lens in Patients with Aniridia
}

\author{
Arjun Srirampur, MS, FRCS; Pasyanthi Balijepalli, MS
}

Anand Eye Institute, Habsiguda, Hyderabad, India

\section{J Ophthalmic Vis Res 2020; 15 (4): 584-584}

Dear Sir,

We read with great interest the article by $\mathrm{Al}-$ Rashidi $\mathrm{SH}$ on black diaphragm intraocular lens $(\mathrm{IOL})$ in patients with Aniridia. ${ }^{[1]}$ We would like to congratulate the author for the interesting and well-written paper, but we have some concerns regarding the article.

First, the author should have mentioned the site and size of the corneal incision made for the implantation of the IOL. As these IOLs are quite bulky, it would require at least a $9 \mathrm{~mm}$ incision to insert them into the anterior chamber. Such a large incision has the potential to damage the limbal stem cell population which may subsequently accelerate epithelial healing problems in patients with aniridia.

Furthermore, these patients are prone to develop intraocular pressure elevation in the long term which may need a glaucoma filtering surgery, therefore it would be prudent to spare the superior limbus for possible future glaucoma procedures.

Second, most previous reports on the long-term results of aniridia IOLs mention a high risk of postoperative cystoid macular edema (CME) and IOP elevation due to direct contact of the IOL haptics with the trabecular meshwork. ${ }^{[2,3]}$ It would have been nice if this paper could have provided

Correspondence to:

Arjun Srirampur, MS, FRCS. Consultant - Cornea, Cataract and Refractive surgery, Anand Eye Institute, Habsiguda, Hyderabad 500007, India.

E-mail: sarjuneye@gmail.com

Received: 11-02-2019 Accepted: 29-04-2019

\section{Access this article online}

Website: https://knepublishing.com/index.php/JOVR

DOI: 10.18502/jovr.v15i4.7801 details of the postoperative status stating whether any patient developed CME.

Third, as mentioned earlier, glaucoma is the most commonly reported complication of black diaphragm IOL implantation. Most previous reports state risks as high as $40 \% .{ }^{[4]}$ But it is surprising to note that none of the patients in this study developed postoperative glaucoma in the followup period. On the contrary, all patients who were on anti-glaucoma medications preoperatively and did not require any medications in the postoperative period.

\section{Financial Support and Sponsorship}

Nil.

\section{Conflicts of Interest}

There are no conflicts of interest.

\section{REFERENCES}

1. Al-Rashidi. Black diaphragm intraocular lens implantation in patients with aniridia. J Ophthalmic Vis Res 2019;14:2731.

2. Aslam SA, Wong SC, Ficker LA, MacLaren RE. Implantation of the black diaphragm intraocular lens in congenital and traumatic aniridia. Ophthalmology 2008;115:1705-1712.

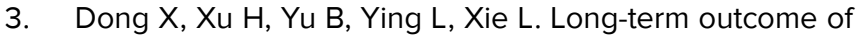
black diaphragm intraocular lens implantation in traumatic aniridia. Br J Ophthalmol 2010;94:456-459.

4. Reinhard T, Engelhardt S, Sundmacher R.Black diaphragm aniridia intraocular lens for congenital aniridia: long-term follow-up. J Cataract Refract Surg 2000;26:375-381.

This is an open access journal, and articles are distributed under the terms of the Creative Commons Attribution-NonCommercial-ShareAlike 4.0 License, which allows others to remix, tweak, and build upon the work non-commercially, as long as appropriate credit is given and the new creations are licensed under the identical terms. 